\title{
The relation between opinion and behavior related to abortion among Brazilian professionals for whom religion is very important, is different than among all other groups
}

\author{
Faundes $\mathrm{A}^{1,2 *}$, Bento $\mathrm{SF}^{1,3}$, Padua $\mathrm{KS}^{1,3}$, Duarte $\mathrm{GA}^{1}$, Torres $\mathrm{JH}^{4}$ and Osis $\mathrm{MJD}^{2,5}$ \\ ${ }^{1}$ Center for Research in Human Reproduction of Campinas (CEMICAMP), Brazil \\ ${ }^{2}$ Department of Obstetrics and Gynaecology, Faculty of Medicine, State University of Campinas, Brazil \\ ${ }^{3}$ Women's Hospital "Professor Doutor José Aristodemo Pinotti" - Center for Integral Attention to Women (CAISM), State University of Campinas, Brazil \\ ${ }^{4}$ Judge, Professor of Criminal Law of Catholic University of Campinas (PUCCAMP), Member of the Brazilian Institute of Criminal Sciences - IBCCRIM and \\ Member of the Judges for Democracy Association \\ ${ }^{5}$ Faculty of Medicine, Jundiai, Brazil
}

\begin{abstract}
Objective: To verify whether professionals for whom religion is very important have the same behavior when confronted with an unwanted pregnancy than those who do not give great relevance to religion.

Method: Secondary analysis of the data collected in four different surveys among gynecologists-obstetricians, judges and legal prosecutors.

Results: Among respondents who do not give great relevance to religion, the percentage who help their partners to abort or aborted their own unwanted pregnancy was always lower than the percentage in favor of more liberal laws. The opposite was observed among respondents for whom religion is very important; the percentage of them who help their partners to terminate an unwanted pregnancy or aborted their own unwanted pregnancy was always higher (in a single case the same) than the percentage who expressed a liberal opinion on the abortion law, in all the four surveys.
\end{abstract}

Conclusion: Professionals who give great relevance to religion are in practice more liberal on abortion than the opinion they give in the abstract, which is the opposite of the behavior of those who do not give great relevance to religion.

\section{Introduction}

It is well known that religion and religiosity are among the most important factors associated to the opinion and behavior of people in relation to abortion [1-3].

Brazil is a country where the abortion law is quite restrictive as in most of Latin America and Sub-Saharan Africa. It is allowed only to protect women's life and in case of rape [4]. More recently the Supreme Court determined that pregnancy can also be legally terminated in case the fetus was anencephalic [5].

Along the years we have carried out a number of surveys on opinion and behavior related to abortion among different professional group in Brazil, and consistently, we have found that the importance the respondent give to religion is the factor identified as the strongest determinant of their opinion on abortion [6].

We notice, however, that while the difference in opinion between those for whom religion is very important in their life and those for whom religion is not important or do not profess a religion, is very large, a difference or two or three folds. In comparison, the difference in behavior was not equally large. That general observation led us to analyze in more detail, whether there was a real difference in opinion and behavior according to the importance given to religion, particularly when the problem of deciding to terminate or not a pregnancy affects the respondent herself or their partners, when the respondents were males.

\section{Subjects and method}

This is a secondary analysis of data collected in four different cross-section surveys carried out by the Center for Research in Human Reproduction of Campinas, (Cemicamp). Two of these surveys were carried out two years apart among obstetricians and gynecologists affiliated to the Brazilian Federation of Obstetrics and Gynecology Societies (FEBRASGO). One among judges affiliated to "Associação

${ }^{*}$ Correspondence to: Anibal Faundes, Rua Vital Brasil 200, P.O. Box 6181 Cidade Universitária, 13.084-971 Campinas, State of São Paulo, Brazil, Tel. +55 193289 2856, Fax. +55 193289 2440, E-mail: afaundes@uol.com.br

Key words: Induced abortion, Abortion law, Religion, Opinion on abortion, Practice of abortion

Received: March 10, 2018; Accepted: March 26, 2018; Published: March 30 2018 
Faundes A (2018) The relation between opinion and behavior related to abortion among Brazilian professionals for whom religion is very important, is different than among all other groups

dos Magistrados Brasileiros" (Brazilian Judges Association) and the last among legal prosecutors associated to 29 states' associations of these professionals.

In all cases a self-administered questionnaire was sent with the normal correspondence sent by the corresponding associations. It included a letter that explained the purpose of the study and the requested their collaboration by answering the questionnaire A presealed envelop to be used to return the questionnaire was also attached. The percentage of response was of $30.2 \%$ for the first and of $22.4 \%$ second surveys among obstetricians and gynecologists, of $14 \%$ for the survey among judges and of $20 \%$ among legal prosecutors.

We used the data related to the same questions included in the four surveys, related to the respondents opinion on the Brazilian abortion law, where five answers were offered: 1) the law should allow abortion in any circumstance; 2) the circumstances in which abortion is allowed should be increased; 3) the law should remain the same; 4) the circumstances in which abortion is allowed should be reduced and; 5) the law should not permit abortion in any circumstance. Those who answer any of the two first alternatives were classified as being in favor of a less restrictive abortion law.

In another section of the questionnaire we asked if the respondent's partner (if male or herself if female) had ever had an absolutely unwanted pregnancy, and if they had terminated that pregnancy. The males who responded positively to these two questions were classified as helping their partners to abort, and the female who gave the same answer were classified as having a voluntary abortion.

All the original studies were carried out had been submitted to the Ethical review board of the University of Campinas and had been approved.

\section{Results}

\section{Characteristics of the subjects}

The distribution of the participants in the four surveys is shown in table 1 .

Close to one fourth of the participants declared religion was very important for them, except prosecutors among whom, less than $20 \%$ belonged to that category. Between 10 and $15 \%$ of participants declare to have no religion.

\section{Difference between opinion and behavior according to importance given to religion}

The $\mathrm{d}$ ata from $\mathrm{t}$ he $\mathrm{f}$ our s urveys s how that $\mathrm{t}$ he g reater $\mathrm{t}$ he importance the respondents gave to religion, the lower the percentage of respondents who have a liberal opinion on abortion law, who help their partners to have an abortion or who terminated their pregnancy themselves. The difference according to importance given to religion was of between 40 and 50 percentage points for opinion on abortion law, and of between 15 and 20 percentage points (with one single exception) on behavior when confronted with unwanted pregnancies.

Comparing the percentage of respondents in favor of more liberal law with the percentage who terminated an eventually unwanted pregnancy, the pattern was different among respondents for whom religion was very important and all other groups (Table 2).

The percentage of respondents for whom religion is very important who had a liberal opinion of the law was always lower than the percentage who help their partners to terminate an unwanted pregnancy, in all the four surveys. The percentage who aborted their own unwanted pregnancy had a similar behavior, with one minimal exception where there was no difference between the two percentages: in the second survey among obstetricians and gynecologist, $62.5 \%$ were in favor of more liberal laws and $62.6 \%$ aborted their unwanted pregnancies (Table 2).

That was different among all the other groups formed by respondents who gave little or no importance to religion or did not professed any religion. In the case of these three groups of respondents, the percentage who expressed a liberal opinion with reference to the abortion law was always higher than the percentage who terminated an unwanted pregnancy in themselves or in their partners (Table 2).

\section{Discussion}

The results of this analysis show that the professionals who declare that religion is very important in their lives had a behavior that is different than the usual pattern.

The usual observation in most studies is that the proportion of people who give an opinion in favor of abortion is much higher than the proportion willing to act according to that opinion [7]. This is what we observed among the respondents analyzed in this study, who give little or not importance to religion, as well as among those without religion. In all the four surveys analyzed, the percentage of respondents who aborted an unwanted pregnancy was much lower that the proportion who expressed to be in favor of a more liberal abortion law. The opposite was observed among the respondents in the four surveys, who declare that religion was very important in their lives. The percentage that aborted an unwanted pregnancy was higher than the percentage who were in favor of more liberal abortion law.

We did not find any publication on this subject exploring the behavior of people who expressed that religion was a key element on their lives, which leave us without a reference to compare our results.

The professional submitted to these four survey were highly educated people aware of the problem of unsafe abortion in Brazil, and consequently, it was not very surprising that between 40 and $50 \%$ of those for whom religion was very important were in favor of more liberal abortion laws, although those percentage were significantly lower that among the other groups for whom religion was not that important.

What has not been described, to the best of our knowledge, is that in this group of individuals who give great relevance to their religion the percentage who abort when confronted with an unwanted pregnancy, is much higher that the percentage who express an opinion in favor of more liberal abortion laws.

We have no reasons to doubt of the sincerity of those who were in favor of keeping the law restrictive or of making it more restrictive, but who terminated an unwanted pregnancy. We know that the dilemma of abortion is understood differently according to the proximity of the problem to us [8]. It is easy to be oppose to abortion as long as it doesn't affect us directly, neither to any body close to us, and if our religion prohibit abortion, we express our opinion in favor of keeping or expanding restrictive laws, in the belief that a restrictive law will reduce its number. Because our samples were constituted by usually well-informed professionals, the percentage in favor of less restrictive laws is much higher than expected, but still significantly lower than among those who do not give great importance to religion.

The new information derived from this analysis is that we have to consider the stated opinion on abortion of people for whom 
Faundes A (2018) The relation between opinion and behavior related to abortion among Brazilian professionals for whom religion is very important, is different than among all other groups

Table 1. Socio-demographic characteristics of the participants in the four surveys

\begin{tabular}{|c|c|c|c|c|}
\hline \multirow[t]{2}{*}{ Características } & $\begin{array}{c}\text { Gyn Obst } \\
\left(1^{\text {st }} \text { survey }\right)\end{array}$ & $\begin{array}{l}\text { Gyn Obstet } \\
\left(2^{\text {nd }} \text { survey }\right)\end{array}$ & Prosecutors & Judges \\
\hline & N $\quad(\%)$ & N (\%) & N (\%) & N $(\%)$ \\
\hline \multicolumn{5}{|l|}{ Age (years) } \\
\hline Up to 39 & $1423(33.4)$ & $1036(31.0)$ & $1082(41.4)$ & $340(22.8)$ \\
\hline $40-49$ & $1450(34.0)$ & $1081(32.4)$ & $656(25.1)$ & $310(20.8)$ \\
\hline 50 or over & $1343(31.5)$ & $1199(36.0)$ & $837(32.0)$ & $823(55.1)$ \\
\hline Missing & $45(1.1)$ & $21(0.6)$ & $39(1.5)$ & $20(1.3)$ \\
\hline \multicolumn{5}{|l|}{ Sex } \\
\hline Female & $1944(45.6)$ & $1627(48.8)$ & $869(33.2)$ & $364(24.4)$ \\
\hline Male & $2293(53.8)$ & $1710(51.2)$ & $1736(66.4)$ & $1129(75.6)$ \\
\hline Missing & $24(0.6)$ & 0 & $9(0.3)$ & 0 \\
\hline \multicolumn{5}{|l|}{ Marital status } \\
\hline In stable union & $3.370(79.1)$ & $2586(77.5)$ & $1945(74.4)$ & $1.190(79.7)$ \\
\hline Not in current union & $864(20.3)$ & $741(22.2)$ & $659(25.2)$ & $299(20.0)$ \\
\hline Missing & $27(0.6)$ & $10(0.3)$ & $10(0.4)$ & $4(0.3)$ \\
\hline \multicolumn{5}{|c|}{$\begin{array}{l}\text { Importance of religion in the } \\
\text { answers }\end{array}$} \\
\hline Very important & $1193(28.0)$ & $864(25.9)$ & $479(18.3)$ & $372(24.9)$ \\
\hline Little importance & $1087(25.5)$ & $1239(37.1)$ & $661(25.3)$ & $373(25.0)$ \\
\hline None & $1454(34.1)$ & $707(21.2)$ & $906(34.7)$ & $455(30.5)$ \\
\hline No religion & $441(10.4)$ & $395(11.8)$ & $424(16.2)$ & $214(14.3)$ \\
\hline Missing & $86(2.0)$ & $132(4.0)$ & $144(5.5)$ & $79(5.3)$ \\
\hline \multicolumn{5}{|l|}{ Number of living children } \\
\hline None & $938(22.0)$ & $719(21.5)$ & $721(27.6)$ & $262(17.5)$ \\
\hline $1-2$ & $2159(50.7)$ & $1709(51.2)$ & $1233(47.2)$ & $612(41.0)$ \\
\hline$\geq 3$ & $1144(25.8)$ & $897(26.9)$ & $630(24.1)$ & $614(41.1)$ \\
\hline Missing & $20(0.5)$ & $12(0.4)$ & $30(1.2)$ & $5(0.3)$ \\
\hline Total & 4261 & 3337 & 2614 & 1493 \\
\hline
\end{tabular}

Table 2. Percentage of respondents who declared that abortion laws should be less restrictive, who helped them partners to abort or induced their own abortion, according to the importance they give to their religion

\begin{tabular}{|c|c|c|c|c|}
\hline & $\begin{array}{c}\text { Importance of religion for the } \\
\text { subject }\end{array}$ & $\begin{array}{l}\text { Declared abortion law } \\
\text { should be less restrictive }\end{array}$ & $\begin{array}{c}\text { Helped his } \\
\text { partner to abort }\end{array}$ & $\begin{array}{l}\text { Had an induced } \\
\quad \text { abortion }\end{array}$ \\
\hline \multirow{4}{*}{$\begin{array}{l}\text { Obstet. Gynecologists } \\
1^{\text {st }} \text { survey }\end{array}$} & $\operatorname{Much}(\mathrm{n}=1193)$ & $61.4^{*}$ & $68.7^{\# \#}$ & $69.0^{\# \#}$ \\
\hline & Not much $(\mathrm{n}=1087)$ & 83.9 & 80.2 & 73.6 \\
\hline & None $(n=1454)$ & 89.3 & 84.5 & 85.1 \\
\hline & No religion $(\mathrm{n}=441)$ & 89.2 & 83.1 & 84.4 \\
\hline \multirow{4}{*}{$\begin{array}{l}\text { Obstet. Gynecologists } \\
2^{\text {nd }} \text { survey }\end{array}$} & Much $(n=864)$ & $62.6^{\#}$ & $71.4^{\# \#}$ & $62.5^{\#}$ \\
\hline & Not much $(\mathrm{n}=1239)$ & 88.6 & 82.3 & 80.7 \\
\hline & None $(n=707)$ & 91.7 & 78.0 & 84.6 \\
\hline & No religion $(\mathrm{n}=395)$ & 95.8 & 87.8 & 90.5 \\
\hline \multirow{4}{*}{ Judges } & Much (n=372) & $46.7 *$ & $76.5^{* *}$ & $57.1 *$ \\
\hline & Not much $(n=373)$ & 84.6 & 71.4 & 66.7 \\
\hline & None $(n=455)$ & 90.6 & 81.4 & 77.8 \\
\hline & No religion $(\mathrm{n}=214)$ & 96.1 & 85.4 & 78.6 \\
\hline \multirow{4}{*}{ Prosecutors } & Much $(n=479)$ & $43.6^{\#}$ & $60.5^{* *}$ & $75.0^{*}$ \\
\hline & Not much $(n=661)$ & 80.8 & 64.4 & 70.0 \\
\hline & None $(\mathrm{n}=906)$ & 87.0 & 75.6 & 82.6 \\
\hline & No religion $(\mathrm{n}=424)$ & 90.1 & 68.3 & 94.1 \\
\hline
\end{tabular}

*Invalid chi-square; ** Not significant; \# $\mathrm{p}<0.001$; \#\# $\mathrm{p}<0.05$

religion is very important, with care, because that opinion can change considerably when the issue of an unwanted pregnancy affects directly to them or their partner. Asking simply of the opinion on abortion in abstract may give a distorted vision of the reality.

\section{Conclusion}

Professionals who give great relevance to religion are in practice more liberal on abortion than the opinion they give in the abstract, which is the opposite of the behavior of those who do not give great relevance to religion.

\section{References}

1. Faúndes A, Duarte GA, Osis MJD, Andalaft-Neto J (2007) Variations in the knowledge and opinions of Brazilian gynecologists and obstetricians on legal abortion between 2003 and 2005. Rev Bras Ginecol Obstet 29: 192-199.

2. Harris LH, Cooper A, Rasinski KA, Curlin FA, Lyerly AD (2011) Obstetrician gynecologists' objections to and willingness to help patients obtain an abortion. Obstet Gynecol 118: 905-912. [Crossref]

3. Rehnstrom Loi U, Gemzell-Danielsson K, Faxelid E, Klingberg-Allvin M (2015) Health care providers' perceptions of and attitudes towards induced abortions in subSaharan Africa and Southeast Asia: a systematic literature review of qualitative and quantitative data. BMC Public Health 15: 139. [Crossref] 
Faundes A (2018) The relation between opinion and behavior related to abortion among Brazilian professionals for whom religion is very important, is different than among all other groups

4. Oliveira J, organizador (1996) Criminal Code: Decree-Law no. 2,848, dated 12/12/1940, updated and accompanied by complementary legislation. 34. ed. São Paulo: Saraiva

5. Diniz D (2016). The Architecture of an Action in Three Acts - Anencephaly in the STF. University of Brasília Law Journal (Derecho.UnB) 1:2.

6. Osis MJD, Faúndes A, Duarte GA, Makuch MY (2013) The role of religiosity on Brazilian gynecologists' perspective and conduct regarding induced abortion Bagoas 9: 87-107.
7. Faundes A, Pádua KS, Bento S, Miranda L and Alves GD (2017) Opinion about Women's Right to Abortion after Rape, and Willingness to Provide Safe Abortion Services by Brazilian Obstetricians and Gynecologists. J Gynecol 2: 000S3-002.

8. Faundes A, Duarte GA, Andalaft-Neto J, Sousa ME (2004) The Closer You Are, the Better You Understand; the Reaction of Brazilian Obstetrician-Gynaecologists to Unwanted Pregnancy. Reprod Health Matters 12: 47-56. [Crossref]

Copyright: $(2018$ Faundes A. This is an open-access article distributed under the terms of the Creative Commons Attribution License, which permits unrestricted use, distribution, and reproduction in any medium, provided the original author and source are credited. 